\title{
A Conceptual Framework for Flood Impact Mitigation through Transboundary River Management
}

\author{
Georgina Clegga, ${ }^{\mathrm{a}}$, Richard Haigh ${ }^{\mathrm{a}}$, Dilanthi Amaratunga ${ }^{\mathrm{a}}$, Harkunti Rahayu ${ }^{\mathrm{b}}$, Harshinie Karunarathna ${ }^{\mathrm{c}}$, \\ Deni Septiadi ${ }^{\mathrm{d}}$ \\ ${ }^{a}$ Global Disaster Resilience Centre, University of Huddersfield, Queensgate, Huddersfield, HD1 3DH, United Kingdom \\ ${ }^{b}$ School of Architecture, Planning and Policy Development, Institute of Technology Bandung, Bandung, 40132, Indonesia \\ ${ }^{c}$ College of Engineering, Swansea University, Swansea, SA1 8EN, United Kingdom \\ ${ }^{d}$ School of Meteorology, Climatology and Geophysics, Tangerang, Indonesia \\ Corresponding author: ${ }^{*}$ g.clegg@hud.ac.uk
}

\begin{abstract}
Successful mitigation of flood risk requires an integrated, basin-wide approach. This is particularly important in transboundary river basins, where the actions of multiple stakeholders must be coordinated. The Ciliwung River, Indonesia, presents an example of a complex urban basin that crosses multiple administrative borders. The increasing frequency and severity of floods in the downstream capital city of Jakarta has highlighted the need for better river governance arrangements. However, it is unclear what form these arrangements should take. This paper aims to develop a conceptual framework that identifies the key concepts relevant to flood management and governance in transboundary river basins and how they relate to the situation in the Ciliwung. Key concepts were drawn from a review of the literature conducted using online databases and search engines. The framework firstly outlines the flood hazard itself in terms of drivers and impacts. It then goes on to establish the associated governance arrangements and identifies any interdependencies. The framework highlights multiple interrelated drivers of flood risk, both human and physical. There is also a range of governance issues related to capacities, coordination of institutions, and fragmentation of plans and policies. Due to flood risk and river management complexities, this conceptual framework provides much-needed clarity to develop improved management arrangements in the Ciliwung River Basin. It also sets a framework to facilitate future research on transboundary management in relation to flood risk in other urban and peri-urban river basins.
\end{abstract}

Keywords - Ciliwung River; flood; Indonesia; Jakarta; integrated flood risk management; river governance; transboundary.

\section{INTRODUCTION}

Floods have the highest frequency and widest geographical distribution of any natural hazard worldwide [1]. Despite efforts to manage to flood and reduce its impacts, trends show that there has been a steady rise in the frequency of floods experienced around the world [2]. With this, the number of people affected and economic impacts are growing [3].

Evidence from Jakarta, Indonesia's capital city, demonstrates this growing flood trend, where the impacts of floods have increased in severity in recent years. Major floods in 1996, 1999, 2002, 2007, 2013, and 2014 resulted in unprecedented levels of damage [4]. In January 2013, floods displaced 40,000 people and incurred 775 million US Dollars in damages [5]. Recent floods in January 2020 resulted in 66 deaths and displaced 36,000 people [6], exemplifying the scale of this serious problem.

Increased flooding is caused by physical, social, economic, and political drivers [7], [8]. These drivers are multiple, interrelated, and interacting, meaning that to address flooding successfully, a holistic and integrated approach is required, with coordinated action between institutions and across sectors. Such calls for unified flood management are reflected across Integrated Water Resources Management (IWRM) and Integrated Flood Risk Management (IFRM) principles. Contemporary IFRM acknowledges that activities within a river basin are interconnected and interdependent, as such, they should be coordinated across the basin [9]. It also recognizes that a spectrum of actions is required to address the diversity of flood risk drivers and promotes traditional 'hard' engineering in combination with 'softer' measures (for 
example, sustainable planning and development) in order to address flooding holistically. Nevertheless, the effective implementation of such ideals can be a challenging task. This is especially true in transboundary river basins (those that cross political-administrative borders) where the number of actors is multiplied and where coordination challenges are compounded by different political, legal, institutional, and technical environments across which to coordinate [10]. The interconnectedness of the river system means that actions in one location can have (potentially negative) impacts elsewhere in the basin [3].

The Ciliwung River is an example of a transboundary river that flows through Jakarta. In total, the river passes through two provinces (West Java and the Special Region of Jakarta) and four municipalities (Bogor Regency, Bogor City, Depok City, and Jakarta City). Indonesia's decentralized government system means that each of these municipalities has the authority to make its plans and address its priorities. Decentralization has also resulted in more institutions responsible for flood management distributed across various levels of governance (national, provincial, municipal) [11]. Although decentralization can contribute to good governance, it can also lead to fragmentation of policies and plans, both horizontally across different administrations and vertically between levels of governance. This fragmentation presents a particular concern for coordinated management of flood risk. The growing flood problem in downstream Jakarta has highlighted the urgent need for more integrated river governance and flood management arrangements for the Ciliwung River Basin (CRB).

This paper presents a conceptual framework that was developed to support the generation of improved river governance and flood management plans for the Ciliwung Basin. The framework aims to highlight the key concepts relevant to the management of flooding in the CRB and seeks to identify any relationships between them. The framework was developed as part of the project 'Mitigating hydrometeorological hazard impacts through improved transboundary river management in the Ciliwung River Basin'. This three-year interdisciplinary project aims to understand how transboundary river governance arrangements in the CRB influence flood hazard impacts and develop plans for improved transboundary governance arrangements to manage the floods.

The remainder of this paper is structured as follows: Firstly, the methods used to develop the framework are presented. The conceptual framework is then organized into three subsections: flood risk drivers, flood impacts, and transboundary governance and river management. Finally, a discussion and summary of the framework is provided.

\section{MATERIAl AND Method}

Miles and Huberman [12] describe a conceptual framework as something that "explains either graphically or in narrative form, the main things to be studied - the key factors, variables or constructs - and the presumed interrelationships among them" (p. 20). Thus, this framework outlines the key concepts relevant to the management of flooding in an urban transboundary river basin. The framework is structured around three key areas: flood risk drivers, flood impacts and transboundary governance and river management. Key concepts were identified through a literature review. Firstly, for each concept identified, the general background, theory, or global view is presented for understanding. Each concept is then linked to the current situation in the CRB. In cases where no literature was available for the CRB specifically, information was drawn from sources pertaining to the Jakarta area or Indonesia that could provide potentially relevant insights. Regarding information relating specifically to the $\mathrm{CRB} /$ Indonesia, the literature review was limited to the most recent documents available in order to present the current status.

Flood risk drivers were identified from an initial literature search using the following search terms (and terms in combination): e.g. 'flood risk'; 'drivers'; 'causes of [flooding]'. Once an initial list of drivers was identified a second search into each driver itself was carried out in order to gain greater depth. Each term was then searched in conjunction with the following terms: 'Ciliwung River'; 'Jakarta'; 'Indonesia' to identify any previous research conducted at the study location. The same method was applied to identify flood impacts, this time using relevant search terms e.g., 'flood impacts'; 'socio-economic'; 'environmental'; 'human'.

A review of literature relating to transboundary governance and river management was then conducted. For this purpose, Savenije and van der Zaag's [13] framework for sharing international waters was drawn upon. Their framework has three pillars: political, legal/institutional and technical/operational. All three pillars are required to achieve the balanced sharing of waters, with IWRM as the foundation. Although this framework was designed for the management of international waters, many of the same principles apply across borders within a state, therefore it provided a starting point from which key governance and management concepts could be drawn and built upon. Relevant search terms (and terms in combination) included e.g. 'river management', 'transboundary', 'governance', 'transboundary crisis management', 'flood risk management'. As there was limited literature pertaining to transboundary river management in Indonesia, the search was broadened to issues relating to river governance and disaster risk reduction (DRR) in Indonesia that may have bearing.

The literature searches were conducted using online databases and search engines. The review included published journal and conference papers identified through the University of Huddersfield's library and Google Scholar portals and reports published by organisations (e.g. World Meteorological Organisation) identified through online searches (Google).

\section{RESULTS AND DISCUSSION}

\section{A. Flood Risk Drivers}

1) Precipitation: Precipitation may contribute to pluvial flooding, where precipitation exceeds drainage capacity or fluvial flooding, where precipitation increases river discharge to the point where capacity is breached [14]. Precipitation on a large scale is driven by climatological regimes. Jakarta experiences a tropical monsoon climate (type Am, Koppen Climate Classification) [15] which exhibits distinct wet and dry seasons associated with shifts in wind direction. The wet 
season brings heavy monsoon rains, and flooding is common during the peak months of December to February [16].

Several other factors may influence precipitation amounts. High temperatures in the equatorial region generate frequent convective precipitation all year round (not only during the wet season) [17]. Although convective rainfall may be localized and short-lived, it can be intense, generating high accumulations over a short time period.

In addition, orographic lift, the effect of air rising over high ground, can create heavy precipitation in upland regions, such as over the mountains of central Java. Rainfall has been noted to be particularly heavy in the upper CRB [18], with annual rainfall amounts in the upper watershed exceeding $3000 \mathrm{~mm}$ [19].

2) Storm Surge: Extreme weather events such as cyclones can generate heavy rainfall leading to fluvial and pluvial flooding as described above but may also present a driver for coastal flooding via storm surges. A storm surge is a rise in seawater above the expected astronomical tide and forms as a result of strong onshore winds and/or temporary increases in sea level due to low atmospheric pressure driven by the storm [20]. Storm surges have been noted along the Java coastline and may contribute to increased flood risk if in combination with spring tide conditions [21].

3) Climate Change: 'Climate change' refers to increasing global temperatures due to increasing concentrations of atmospheric greenhouse gases and encompasses a range of associated changes in climate phenomena such as sea-level rise and extreme weather events [22]. Such changes are likely to have knock-on effects for pluvial, fluvial, and coastal forms of flooding.

The increase in atmospheric temperatures is expected to influence the frequency and intensity of precipitation, including that produced convectively and that generated by the monsoon. Monsoon rains are expected to intensify due to increases in atmospheric moisture globally, with the likelihood of future increases in precipitation extremes related to the monsoon identified to be very likely for the Southeast Asia region ( $>90 \%$ probability) [23]. There is evidence that precipitation events are becoming more intense in Indonesia, particularly during the wet season [15].

Rising sea levels as a result of ice mass loss and thermal expansion of ocean waters are likely to increase coastal flood risk [24]. In the Jakarta Bay area, altimetry measurements have indicated that sea levels rose at a rate of approximately $6 \mathrm{~mm}$ per year over the period 1993-2012 [25].

4) Geography and Morphology: The geography and morphology of the river basin also play a role in determining the likelihood of flooding. Jakarta is located on a low-lying deltaic floodplain placing the city at risk of coastal flooding. Subsidence of the land due to compaction of alluvial soils further contributes to coastal flood risk. It is estimated that around $40 \%$ of Northern Jakarta lies below sea level, with land subsidence rates between one and fifteen centimeters per year depending on location [26]. The morphology of the river basin and channel can influence the likelihood of overtopping and inundation. For example, basin characteristics determine the rapidity of runoff, influencing the speed at which water reaches the river channel and the speed at which peak flow is reached. Factors that influence runoff speed include stream network density, slope gradient, and soil permeability [14].

5) Land Modification: Deforestation and removal of vegetation are known to impact runoff by reducing interception, evapotranspiration, infiltration, and water storage and increasing erosion and siltation [27]. Modification of hillslopes for agricultural production can alter flow paths, flow velocities, and water storage, and consequently flow connectivity and concentration times [28]. In the upper reaches of the $\mathrm{CRB}$, land has been cleared for agriculture (primarily tea plantations) [19]. Studies have identified an intensification of basin response and increases in peak flow and sediment load attributed to land clearance in recent years [11], [18].

6) Population Growth: Global population has increased exponentially over time and is expected to continue to increase in the future, with Indonesia finding a significant proportion. Fifty percent of the population growth between 2017 and 2050 is anticipated to be concentrated in nine countries. Indonesia is the ninth by expected contribution [29]. With the growing population, there is a growing number of people exposed to flood risk. It has been estimated that approximately 21 million people are already exposed to river floods alone worldwide. This could more than double to 54 million by 2030 as a result of socio-economic development and climate change [30].

7) Rapid Urbanisation: Population growth increases demand for housing, services, and infrastructure, driving urbanization. With urban expansion spreading into floodprone areas, a greater number of people and assets are placed at risk of flooding. Guneralp and colleagues [31] estimated that by $2030,40 \%$ of total global urban land will be located in high-frequency flood zones compared to $30 \%$ in 2000 . They note that urban expansion is likely to contribute to increased flood risk in the future, even without the additional effects of climate change. In developing countries, the rapidity of population growth has exceeded the capacity of governments to meet development demands and has led to poorly planned and managed urban development. This has contributed to the spread of urban areas into flood risk zones [32] and has led to development that, for example, lacks consideration for appropriate drainage measures [7]. The Jakarta urban area increased an estimated 200 times between 1972 and 2012 [18]. However, it has been noted that this rapid urban development occurred faster than the development of plans to guide it [33]. Urbanization both upstream and downstream, plus very low availability of permeable green space in the city, has contributed to reduced infiltration and increased runoff [34]. It is projected that with no future land use controls the CRB will be fully urbanized by 2040 . This will lead to significant increases in flood peak and volume [35]. The development of wetland areas and modification of waterways has also acted to reduce drainage and retention capacity, increasing flood risk further [4]

8) Socio-Economic Conditions: Social vulnerability is the product of social inequalities and places inequalities. It is determined by access to resources, political representation, social capital, social networks, and socio-economic status [36]. Those with higher social vulnerability are often more at 
risk of flooding than others [8]. Urban development and the increased cost of living in Jakarta have placed the urban poor into marginalized spaces, leading to the development of illegal settlements along many of the city's rivers. In particular, the banks of the Ciliwung are heavily populated, placing marginalized groups at greater risk of flooding [37]. The Jakarta Government often blames riverbank settlers for increased flood impacts as these settlements have increasingly encroached into flood risk zones. This has led to initiatives that seek to relocate riverbank settlers elsewhere [38, 39]. However, residents are sometimes reluctant to relocate because their livelihoods depend on being located in the city or close to the river/coast [37]. Texier [38] notes that these socially and economically related processes within the city have forced the vulnerable into hazard zones. In this sense, socio-economic conditions drive vulnerability and exposure and present a significant driver for flood risk.

9) Land Subsidence: Subsidence of the land surface in relation to sea level can increase the risk of coastal flooding. In Jakarta, land subsidence has both anthropogenic and physical drivers [40]. Due to the situation of Jakarta on an alluvial flood plain, natural compaction of the soils has contributed to the reduced elevation of the land. Human activities further compound this. Rapid population growth has resulted in urban development and increased rates of groundwater extraction to meet demand. This groundwater consumption has contributed to increased subsidence. In addition, impermeable urban surfaces reduce groundwater recharge, and the built environment's added weight has further exacerbated the problem. Studies have indicated that soil water extraction is one of the greatest contributing factors to subsidence along with urban development [26].

\section{B. Flood Impacts}

1) Human: Of all-natural hazards, floods have impacted the most people in the $21^{\text {st }}$ Century. In 2018, floods accounted for $24 \%$ of natural hazard-related deaths (the second largest cause behind earthquakes) and $50 \%$ of the total number of people affected by natural hazards [41]. Such impacts include displacement, loss of life, livelihood, and health issues. In Jakarta, the 2007 flood event was one of the most severe experienced by the city and resulted in over 58 fatalities. The floods were also recorded to have secondary impacts on human health. For example, outbreaks of Dengue, Leptospirosis, and Diarrhea were recorded after the event, associated with poor water hygiene (OCHA in [38]). Major flooding in 2013 displaced an estimated 40,000 people [5]. Residents impacted by floods often move to temporary accommodation if they are evacuated or may relocate permanently if their homes are damaged [5]. In particular, the informal settlements that line the riverbanks in Jakarta can be susceptible to flood damage, resulting in the displacement of these populations [38]. Floods can also impact heavily on peoples' livelihoods by affecting their ability to carry out daily activities and by preventing people from accessing their place of work [42]. Those who work in the informal sector and those relying on vulnerable industries, such as fishing, are particularly at risk [38].

2) Economic: Flooding in urban environments can heavily impact the economy through damages to buildings, utilities, housing, household assets, and transport systems, resulting in losses in industry, trade, and employment [7]. The major floods in Jakarta in 2002, 2007, 2013, and 2014 resulted in billions of dollars of economic damage. Estimated total losses incurred from the 2007 and 2013 severe flood events were 565 million US Dollars and 775 million US Dollars, respectively [5].

The greatest economic damages in Jakarta are associated with flooding in the central business district (CBD) where inundation has previously forced businesses and government agencies to close, hindering economic activity [43]. The disruption of the transport networks can further impact businesses in the CBD during floods [44]. Economic losses due to property damage are also significant. The greatest proportion of losses during the 2007 flood event was suffered by the residential sector, accounting for $74 \%$ of losses (BAPPENAS in [5]).

Climate change is likely to increase economic damages from flooding globally. It is estimated that depending on the socio-economic scenario applied, a 1.5-degree Celsius increase in temperature could increase directly incurred flood damages by between $160 \%$ and $240 \%$ [45]. In Jakarta, Hallegatte et al. [46] calculated that there could be over a $50 \%$ increase in average annual losses from coastal flooding in 2050 compared to 2005 under a scenario of optimistic sea level rise and where current flood defense standards are maintained. Under more pessimistic scenarios, where no adaptation occurs (no defense upgrade), the mean increase in losses could be over $1000 \%$.

3) Environmental: Floods can have positive impacts on the natural environment, for example, by providing nutrients and recharging groundwater. However, floods can also cause degradation, especially in areas where natural systems have already been weakened by human activity [47]. As Jakarta is highly urbanized, floods impact most greatly on the built environment. During the 2007 flood, approximately $70 \%$ of Jakarta was inundated [33], with the highest flood level being 3.5 meters measured in the area of Kampung Melayu [48]. In a survey of households in the west and south Jakarta, Wijayanti and colleagues [5] found that on average, homes were inundated to a height of $86 \mathrm{~cm}$, which lasted on average 98 hours during the January 2013 event, resulting in significant damage to the built environment.

\section{Transboundary Governance and River Management}

1) Political: Political will is often cited as necessary for creating an enabling environment for cooperation in transboundary basins $[13,49]$. Political will determines how much cooperation takes place by either supporting or undermining it. Differing political will across borders may also present a barrier to coordination, as it is often the actor with the most power that gains control [50]. Under Indonesia's Law of Regional Autonomy (Law 23/2014), each local government has the authority to enact its regulations and implement its plans [19]. While this has allowed local priorities to be addressed, it has not supported cooperation between local governments. In many jurisdictions, local governments have focused on the generation of local revenue. This has resulted in the exploitation of local resources [51] with little consideration for neighboring areas [52], [53]. Local governments often do not perceive the need to 
coordinate [51], and in some cases, governors have been skeptical about cooperating with others for fear of interference with their administration [52]. This lack of political will for cooperation presents a potential challenge for integrated flood and river management in the basin.

Leadership changes may impact political will. A change in leadership may lead to alterations in policies and implementation strategies impacting (either positively or negatively) flood and river management. In Jakarta, Sagala and colleagues [52] identified that leadership has been a significant influence on the progress of flood mitigation plans, with some Jakarta governors having pushed forward flood mitigation efforts, while others have not.

Another key political aspect is capacity. Capacity building ensures that all parties have the adequate resources to take cooperative action and helps to even out disparities in capacity between actors so that coordination can take place [13]. However, capacity building for coordination is a work in progress in many transboundary basins around the world [10]. In Indonesia, some local governments have developed to a greater extent under decentralization than others, leading to varying capacities across administrative borders, which may contribute to difficulties in cross-border collaboration [53]. Limited local capacity can also prevent local institutions from conducting their roles. For example, the provincial disaster management office (BPBD) often lacks sufficient funds and staffing to perform its role [54] fully.

There are many different sectors concerned with flood management, such as planning, land use, agriculture and forestry, and so on [55]. For effective flood management, these sectors should align and coordinate their activities [13, 56], making sectoral integration another key political aspect for successful transboundary management. However, government sectors more commonly work unilaterally. Government departments tend to have their specific remits, priorities, and perspectives [13]. This divided mode of working is associated with issues such as institutional fragmentation and unclear responsibilities.

With varying needs between locations (e.g., upstream and downstream) in a transboundary river basin, the priorities of one sector may not be aligned with the priorities of the same sector in another jurisdiction elsewhere in the basin [13]. For example, the risk of flooding may be different. Therefore, flood risk reduction may be a priority in one location but not in the other. Diverging priorities can lead to further fragmentation and can potentially lead to conflict without coordinated plans. Similar sectoral fragmentation has been identified within the CRB. For example, the municipalities of Bogor and Depok have independent planning systems that are not well integrated, exhibiting fragmentation and limited collaboration [19].

2) Legal: Savenije and van der Zaag [13] suggest that a clear legal framework provides the basis for successful management. This may include national laws, regulations, directives, or international agreements and treaties [57]. However, in many cases, transboundary agreements are still lacking. It has been found that a large proportion of the transboundary basins across the globe still lack common treaties, or if they do have them, they lack the principles of customary law [10]. It has been suggested that more effort is needed to negotiate and implement transboundary agreements.
Indonesia has several laws relevant to the management of flood risk, including the Disaster Management Law (26/2007), the Water Law (07/2004), and the Spatial Planning Law (26/2007). However, there are limited laws for transboundary cooperation between administrative areas. Although the central government created regulation for the implementation of an inter-local-government partnership to coordinate local governments, the regulation has been suggested to be too simplistic to tackle the complexity of this task [51].

Law enforcement also needs to be considered, as a law that is not enforced is not effective. Indonesia exhibits a highly bureaucratic legal system, with many different legislative acts and regulations [58]. However, several authors have identified that some laws are not fully implemented or enforced [11], [33], [58]. For example, Grady and colleagues [54] identify low levels of compliance with legislation relating to spatial planning and building codes, which could impact flood risk.

3) Institutional: An important part of successful institutional arrangements is how the various institutions coordinate with one another. This includes both vertical and horizontal coordination, as well as how stakeholders and the public can participate. Within decentralized governance structures, responsibilities for FRM may be distributed across various levels, from national to local. Issues can arise where there is a lack of coordination between government levels, resulting in inconsistencies between national and local strategies. For cooperation to take place, it is important that each organization clearly understands who the other actors are and how responsibilities are distributed between them to avoid overlapping or duplicated action [7].

Indonesia moved from a centralized to a decentralized governance system in 1999. However, disconnects between policies at different levels have been observed. Although responsibility was transferred to various levels of governance under decentralization, it has been noted that a similar transfer of power and resources did not occur. The provincial-level are found to have limited power, creating a gap between the national level to the local levels [54]. Furthermore, it has been identified that provinces lack strategic and operational plans for DRR, which creates a policy disconnect with the national level [54].

In Greater Jakarta, a lack of clear responsibilities between local, provincial, and central government authorities has been noted, hindering cooperation [51]. Overlapping responsibilities have also been identified, for example, between BBWSs (river basin authority) and PJT (bulk water supply corporation), which has contributed to reduced efficiency and accountability problems [59]. According to Dewi and van Ast [60], several regulations in Indonesia mandate cooperation between governance levels; however, they note that there is little coordination in practice. For example, BKSP (Badan Kerja Sama Pembangunan Jabodetabekjur) is the inter-local government cooperation agency and consults with the central government on development matters. However, BKSP lacks the authority to implement and enforce, which means that little coordination actually takes place [53].

As rivers are connected from upstream to downstream, actions taken upstream may influence regions downstream. Therefore plans should also be coordinated horizontally 
throughout the basin [3]. For this, Indonesia has a river basin management system. This involves applying river basin management units (Wilayah Sungai, WS) and basin authorities (BBWS). BBWS act as river basin regulators and, as part of this, provide a coordinating function among stakeholders [59]. Basin plans are also developed at the WS scale [61], [62]. This system would appear to follow IWRM principles on paper, as management and planning appear to take place at the basin level. However, the basin management plans are not widely applied in practice, and coordination at the basin level tends to be limited [61]. Thus, horizontal coordination is not supported in practice.

Stakeholder and public engagement in river management is important for developing sustainable and equitable solutions and ensuring national decisions are compatible with local needs [13]. For the most part, governors of Jakarta have taken a top-down approach to governance, which has not fostered participation widely [4], [58]. Although some governors have given more attention to participation [52], recent flood management plans, such as those for the new seawall construction, have been noted to lack stakeholders' participation in their design [4]. In general, citizens tend to be excluded from decision-making processes [58]. In addition to the attitudes of leaders, socio-economic factors further compound the lack of participation. Poverty, poor education, limited access to services, livelihood profiles, and cultural beliefs may affect the ability of people to engage [13], [63].

4) Technical/Operational: This section concerns key aspects of technical and operational procedures, including the management strategy taken, data and information sharing procedures, and the integration of climate change adaptation into flood management.

IFRM principles suggest that engineered flood mitigation measures should be applied with other non-engineered approaches [7]. The approach to flood management in Jakarta has been predominantly structural. This has included a series of dams, flood gates, polders, and sea walls. However, this approach to flood management focused heavily on structural measures and has been criticized for focusing only on managing the hazard and with little consideration for underlying vulnerabilities [4], [38]. Without proper consideration for underlying risk factors, flood risk cannot be comprehensively addressed. Furthermore, continued maintenance of existing structural measures is necessary to ensure their functionality. Poor management and maintenance of structural measures in some cases have resulted in reduced performance. For example, due to the lack of maintenance of flood retention basins in Jakarta, some now operate at only $30 \%$ of their original capacity [64].

Data and information are crucial technical aspects for effective IFRM. Data and information are required for each stage of the risk management cycle [57], and should include both physical and social aspects [65] for a fully integrated approach. It is clear that for effective management, a variety of data should be brought together. However, administrative borders can hinder the transfer of knowledge and information [66], and a lack of suitable mechanisms for data exchange can pose a barrier to successful transboundary management [49]. In a transboundary setting, different actors are likely to be held, which may not necessarily be transparent [67].
Therefore, it can be difficult to identify what information already exists and what information is required, which may lead to duplication. In addition, information may not be easily shared across borders due to different technical concepts, languages, and terminologies [67]. Actors may take different approaches to data collection and management. Thus it can prove difficult to coordinate data sharing [65] effectively. Indonesia's disaster management agency (BNPB) operates an online platform for gathering data on disasters (DIBI) [68]. However, issues have been noted relating to the availability of data from local districts and municipalities. This has been linked to a lack of technical capacity at the local level [69].

Climate change contributes additional pressures and compounds existing water management challenges [50]. Thus, transboundary cooperation for river management is particularly important in areas vulnerable to climate change. It is possible that cross-border conflicts could become more frequent as existing arrangements may not be able to handle the strain of future climate change pressures [70]. Therefore, it is important that future FRM plans are robust to deliver effective coordination and integrate an element of flexibility to adapt to uncertain future climate changes [50]. Plans should also be coordinated across the basin to avoid potential knockon effects and any mal-adaptive practices [71].

The National Action Plan for Climate Change Adaptation (RAN-API) provides Indonesia's overarching CCA plan. While this plan is considered a suitable basis to support adaptation efforts, it has not been widely implemented. There is little incentive for actors to implement the plan, as it is not legally binding [72], and there is also no lead ministry to ensure coordinated implementation of the plan $[72,73]$.

\section{CONCLUSION}

The aim of this study was to develop a conceptual framework that brings together the key concepts to be considered for the management of flooding in a transboundary river basin environment, with a particular focus on the CRB, Indonesia. A diagrammatic summary of the framework is presented in Figure 1. The framework highlights that there are many aspects to be considered in developing effective river management plans for the reduction of flood impacts. Firstly, the drivers of flooding need to be addressed. The drivers of flooding can be considered here as 'external' and 'governable', as shown in Figure 1.

External drivers concern factors that contribute to flooding but cannot be improved by management alone. This includes climate and extreme weather, geography, morphology, natural land subsidence and population growth. On the other hand, governable drivers can be influenced and potentially improved to reduce the likelihood of flooding and the severity of impacts. This includes the way flood management measures are implemented and maintained, land modification, urbanization, social vulnerability, and climate change adaptation considerations. Coordinated action is required to address these factors holistically. There are then further factors that relate to the governance arrangements and approaches themselves. This includes coordination between sectors, institutions, and governance levels and the integration of strategies. 


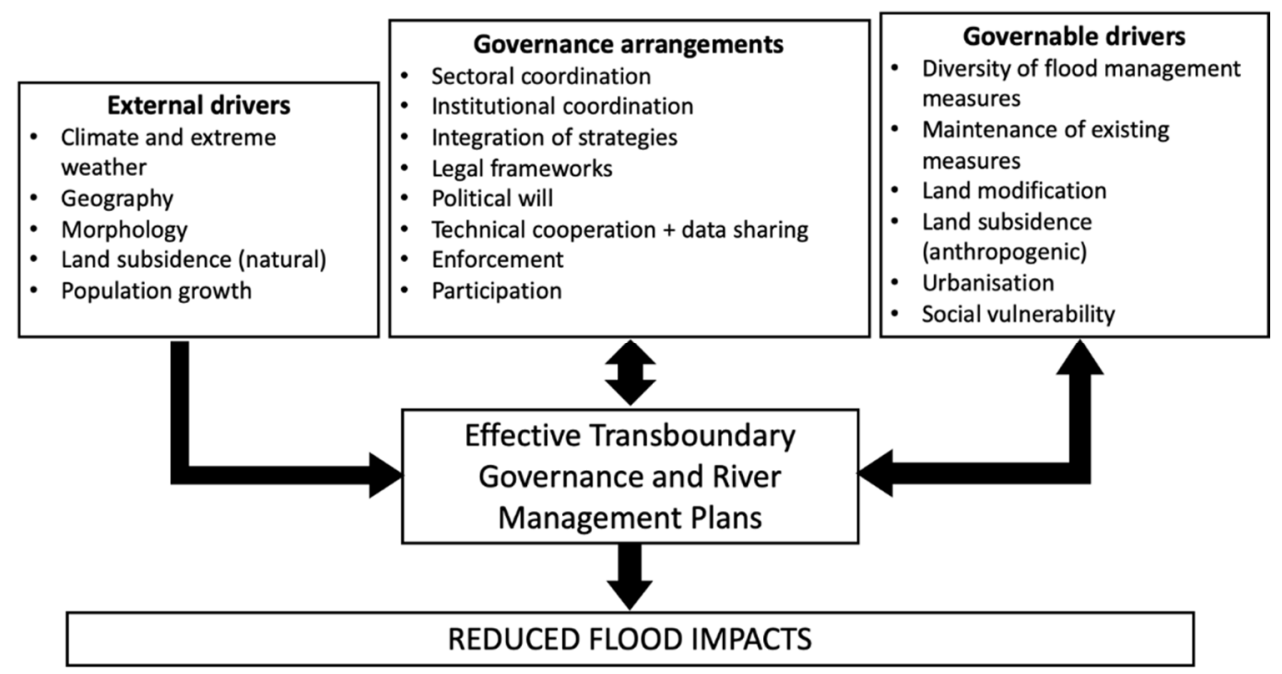

Fig. 1 Diagrammatic summary of the conceptual framework.

The effectiveness of management arrangements is also associated with supporting aspects, such as the availability of legal frameworks, political will, technical cooperation, enforcement, and participation. These aspects can be used to coordinate activities and integrate approaches to be both effective and efficient.

Through highlighting the key concepts relating to transboundary river governance and flood management, and the potential linkages between them, the framework provides a starting point for investigating how transboundary river management plans may be made more effective in the future in the CRB.

This study was based on evidence from the literature alone. For which this framework was developed, the project will go on to collect further empirical data and gain a deeper understanding of the issues outlined above. Future objectives of the project include the development of hydrodynamic and urban flood models for the downstream CRB; identification of the existing transboundary management arrangements and levels of coordination, and the enhancement of basin-wide dialogue between actors. Although the framework was developed with relevancy to the CRB, it has the potential to provide insights relevant to other transboundary river basins in developing urban and peri-urban environments elsewhere.

\section{ACKNOWLEDGMENT}

This work was supported by the Natural Environment Research Council (Grant number: NE/S003282/1); the Economic \& Social Research Council, Newton Fund and the Ministry of Research and Technology / National Agency for Research and Innovation (RISTEK-BRIN).

\section{REFERENCES}

[1] R. Rudari, "Flood Hazard and Risk Assessment," in "Words into Action Guidelines: National Disaster Risk Assessment," U N, Geneva, 2017.

[2] N. Najibi and N. Devineni, "Recent trends in the frequency and duration of global floods," Earth Sys. Dyn., vol. 9, pp. 757-783, 2018.

[3] UNISDR, "Implementation Guide for Addressing Water-related Disasters and Transboundary Cooperation: Integrating disaster risk management with water management and climate change adaptation," in "Words into Action Guidelines," UN, New York and Geneva. ECE/MP.WAT/56, 2018.
[4] M. Garschagen, G. A. K. Surtiari, and M. Harb, "Is Jakarta's New Flood Risk Reduction Strategy Transformational?," Sustain., vol. 10 no. 8, p. 2934, 2018.

[5] P. Wijayanti, X. Zhu, P. Hellegers, Y. Budiyono, and E. C. van Ierland, "Estimation of River Flood Damages in Jakarta, Indonesia," Nat. Haz., vol. 86, no. 3, pp. 1059-1079, 2017.

[6] H. Leung, "66 People Have Died in Indonesia's Devastating Floods. Here's What to Know," 2020, [Online] Available: https://time.com/5761097/jakarta-indonesia-floods/.

[7] A. K. Jha, R. Bloch, and J. Lamond, "Cities and Flooding: A Guide to Integrated Urban Flood Risk Management for the 21st Century," The World Bank, Washington DC, 2012.

[8] K. Goh, "Urban Waterscapes: The Hydro-politics of flooding in a sinking city," Int. J. of Urban Reg. Res., vol. 43, no. 2, 2019.

[9] A. Serra-Llobet, E. Conrad, and K. Schaefer, "Governing for Integrated Water and Flood Risk Management: Comparing Top-Down and Bottom-Up Approaches in Spain and California," Water, vol. 8, no. 10 , p. $445,2016$.

[10] UNEP-DHI and UNEP, "Transboundary River Basins: Status and Trends," UN Env. Prog., Nairobi, 2016.

[11] P. J. Ward, W. P. Pauw, M. W. van Buuren, and M. A. Marfai, "Governance of flood risk management in a time of climate change: The cases of Jakarta and Rotterdam," Env. Pol., vol. 22, no. 3, pp. 518536, 2013.

[12] M. B. Miles, A. M. Huberman, and J. Saldana, S. J, Ed. Qualitative Data Analysis: A Methods Sourcebook, 3rd ed. Los Angeles: Sage Publications Inc., 2014.

[13] H. H. G. Savenije and P. van der Zaag, "Conceptual Framework for the Management of Shared River Basins; with special reference to the SADC and EU," Water Pol., vol. 2, no. 2000, pp. 9-45, 2000.

[14] J. Holden, An Introduction to Physical Geography and the Environment, 4th ed. United Kingdom: Pearson, 2017.

[15] Siswanto, G. J. van Oldenborgh, G. van der Schrier, G. Lenderink, and B. van den Hurk, "Trends in High-daily Precipitation Events in Jakarta and the Flooding of January 2014," in Explaining extreme events of 2014 from a climate perspective, no. 96: American Meteorological Society, 2015.

[16] H. K. B. Tjasyono, R. Gernowo, B. H. Sri Woro, and J. Ina, "The Character of Rainfall in the Indonesian Monsoon," presented at the International Symposium on Equatorial Monsoon System, Yogyakarta, Indonesia, 2008. [Online]. Available: http://file.upi.edu/Direktori/SPS/PRODI.PENDIDIKAN_IPA/BAYO NG_TJASYONO/The_Character_of_Rainfall.pdf.

[17] I. Narulita and W. Ningrum, "Extreme Flood Event Analysis in Indonesia Based on Rainfall Intensity and Recharge Capacity," IOP Conference Series: Earth and Environmental Science, vol. 118, no. 1, p. $012045,2018$.

[18] F. Remondi, P. Burlando, and D. Vollmer, "Exploring the hydrological impact of increasing urbanisation on a tropical river catchment of the metropolitan Jakarta, Indonesia," Sus. Cities Soc., vol. 20, pp. 210-221, 2016 . 
[19] C. Asdak, S. Supian, and Subiyanto, "Watershed Management Strategies for Flood Mitigation: A Case Study of Jakarta's Flooding," Weather and Clim. Extr., vol. 21, pp. 117-122, 2018.

[20] NOAA. "What is storm surge?," 2019, [Online]. Available: https://oceanservice.noaa.gov/facts/stormsurge-stormtide.html. Accessed on Jun. 6, 2019.

[21] N. S. Ningsih, W. Suryo, and S. D. Anugrah, "Study on Characteristics of Residual Water Level in Jakarta, Semarang and Surabaya Waters Indonesia and its Relation to Storm Events in November 2007," Int. J. Basic App. Sci., vol. 11, no. 5, pp. 31-37, 2011.

[22] NASA. "What's in a name? Weather, global warming and climate change," 2019, [Online] Available: https://climate.nasa.gov/resources/global-warming/. Accessed on May $21,2019$.

[23] IPCC, "Climate Change 2013: The Physical Science Basis. Contribution of Working Group I to the Fifth Assessment Report of the Intergovernmental Panel on Climate Change," 2013.

[24] R. J. Nicholls and A. Cazenave, "Sea Level Rise and Its Impact on Coastal Zones," Sci., vol. 328, pp. 1517-1520, 2010.

[25] H. Latief, M. R. Putri, F. Hanifah, I. N. Afifah, M. Fadli, and O. Ismoyo, "Coastal Hazard Assessment in Northern part of Jakarta," presented at the 7th International Conference on Building Resilience, Bankok, Thailand, 27-29th November 2017, 2018.

[26] Nurhamidah, N., Rusman, B., Istijono, B., Hakam, A., \& Junaidi, A. Monitoring and Empirical Modelling for Organic Soil Subsidence Estimation in Sumatra.

[27] H. Chang and J. Franczyk, "Climate Change, Land Use Change and Floods: Toward an Integrated Assessment," Geo. Comp., vol. 2, no. 5, pp. 1549-1579, 2008.

[28] M. Rogger et al., "Land Use Change Impacts on Floods at the Catchment Scale: Challenges and Opportunities for Future Research," Water Res. Res., vol. 53, no. 7, pp. 5209-5219, 2017

[29] United Nations. "World population projected to reach 9.8 billion in 2050 and 11.2 billion in 2100." 2017. [Online]. Available: https://www.un.org/development/desa/en/news/population/worldpopulation-prospects-2017.html. Accessed Jun. 4, 2019.

[30] T. Luo, A. Maddocks, C. Iceland, P. Ward, and H. Winsemius. "World's 15 Countries with the Most People Exposed to River Floods," 2015, World Res. Inst. [Online]. Available: https://www.wri.org/blog/2015/03/world-s-15-countries-mostpeople-exposed-river-floods. Accessed Jul. 11, 2019.

[31] B. Guneralp, I. Guneralp, and Y. Liu, "Changing global patterns of urban exposure to flood and drought hazards," Global Env. Ch., vol. 31 , pp. $217-225,2015$.

[32] A. P. Zischg et al., "Flood risk (d)evolution: disentangling key drivers of flood risk change with a retro-model experiment," Sci. Tot. Env., vol. 639, pp. 195-207, 2018

[33] S. Sagala, J. Lassa, H. Yasaditama, and D. Hudalah, "The Evolution of Risk and Vulnerability in Greater Jakarta: Contesting Government Policy in Dealing with a Megacity's Exposure to Flooding. An academic response to Jakarta Floods in January 2013," in Issue 2 of IRGSC working paper series, 2013.

[34] T. Firman, "The continuity and change in mega-urbanisation in Indonesia: a survey of Jakarta-Bandung Region (JBR) development," Habitat Int., vol. 33, pp. 327-339, 2009.

[35] I. R. Moe et al., "Future projection of flood inundation cosidering landuse changes and land subsidence in Jakarta, Indonesia," Hydro. Res. Lett., vol. 11, no. 2, pp. 99-105, 2017.

[36] S. L. Cutter, B. J. Boruff, and W. L. Shirley, "Social Vulnerability to Environmental Hazards," Social Sci. Q., vol. 84, no. 2, pp. 242-261, 2004

[37] J. Hellman, "Living with floods and coping with vulnerability," Dis. Prev. and Man., vol. 24, no. 4, pp. 468-483, 2015.

[38] P. Texier, "Floods in Jakarta: when the extreme reveals daily structural constraints and mismanagement," Dis. Prev. Man., vol. 17, no. 3, pp. 358-372, 2008

[39] R. van Voorst, "Juxtapositions in Jakarta: How Flood Interventions Reinforce and Challenge Urban Divides," Urban Forum, vol. 31, pp. 373-388, 2020, doi: https://doi.org/10.1007/s12132-020-09391-8.

[40] Y. Budiyono, J. C. J. H. Aerts, D. Tollenaar, and P. J. Ward, "River flood risk in Jakata under scenarios of future change," Nat. Haz. Earth Sys. Sci., vol. 16, pp. 757-774, 2016

[41] CRED, "Disasters 2018: Year in Review," in "CRED Crunch," Centre for Reseach on the Epidemiology of Disasters, 2018. [Online]. Available: https://www.cred.be/publications

[42] R. van Voorst, "Formal and informal flood governance in Jakarta, Indonesia," Habitat Int., vol. 52, pp. 5-10, 2016
[43] M. Caljouw, P. J. M. Nas, and Pratiwo, "Flooding in Jakarta. Towards a blue city with improved water management," J. Hum. and Social Sci. of Southeast Asia and Oceania, vol. 161, no. 4, 2005.

[44] M. Vaswani. "Indoensian capital Jakarta hit by deadly flooding," 2013. [Online]. Available: https://www.bbc.co.uk/news/world-asia21054769 Accessed on Jun. 6, 2019.

[45] EU Science Hub. "Rising danger of deadly river floods with global warming," 2018. Euro. Com. [Online]. Available: https://ec.europa.eu/jrc/en/news/rising-danger-deadly-river-floodsglobal-warming. Accessed on Jun. 122019.

[46] S. Hallegatte, C. Green, R. J. Nicholls, and J. Corfee-Morlot, "Future flood losses in major coastal cities," Nat. Clim. Ch., vol. 3, pp. 802806, Aug. 2013.

[47] C. J. Talbot et al., "The impact of flooding on aquatic ecosystem services," Biogeochem., vol. 141, pp. 439-461, 2018.

[48] Y. Rahmayati, M. Parnell, and V. Himmayani, "Understanding Community-led Resilience: The Jakarta Floods Experience," Aus. J. of Emerg. Man., vol. 32, no. 4, 2017.

[49] C. Skoulikaris and A. Zafirakou, "River Basin Management Plans as a Tool for Sustainable Transboundary River Basins' Management," Env. Sci. Poll. Res., pp. 1-14, 2019, doi: https://doiorg.libaccess.hud.ac.uk/10.1007/s11356-019-04122-4.

[50] M. Zeitoun, M. Goulden, and D. Tickner, "Current and future challenges facing transboundary river basin management," Wiley Interdisc. Rev.: Clim. Ch., vol. 4, no. 5, pp. 331-349, 2013.

[51] T. Firman, "Inter-local-government partnership for urban management in decentralizing Indonesia: from below or above? Kartamantul (Greater Yogyakarta) and Jabodetabek (greater Jakarta) compared," $S p$ Pol., vol. 18, no. 3, pp. 215-232, 2014

[52] S. Sagala, M. Syahbid, and H. Wibisono, "The Role of Leaders in Risk Governance in Jakarta," in Jakarta: Claiming Spaces and Rights in the City, J. Hellman, M. Thynell, and R. van Voorst Eds., 1 ed. London: Routledge, 2018, ch. 6, p. 16.

[53] R. Padawangi and M. Douglass, "Water, Water Everywhere: Toward Participatory Solutions to Chronic Urban Flooding in Jakarta," Pac. Aff., vol. 88, no. 3, pp. 517-550, 2015.

[54] A. Grady, B. Gersonius, and A. Makarigakis, "Taking Stock of Decentralised Disaster Risk Reduction in Indonesia," Nat. Haz. Earth Sys. Sci., vol. 16, no. 9, pp. 2145-2157, 2016.

[55] A. Akhmouch and D. Calavreul, "Flood Governance: A Shared Responsability," in "An application of the OECD Principles on Water Governance to Flood Management," 2019. [Online]. Available: https://www.riob.org/sites/default/files/OECD_Flood\%20governance $\% 20 a \% 20$ shared\%20responsibility_0.pdf.

[56] Dieperink, D. L. T. Hegger, M. H. N. Bakker, Z. W. Kundzewicz, C Green, and P. J. Driessen, "Recurrent Governance Challenges in the Implementation and Alignment of Flood Risk Management Strategies: A Review," Water Res. Man., vol. 30, no. 13, pp. 4467-4481, 2016.

[57] UNECE, "Transboundary flood risk management: experiences from the UNECE region," in "Convention on the Protection and Use of Transboundary Water Courses and International Lakes," UNECE, Geneva, New York, ECE/MP.WAT/31, 2009.

[58] J. Hellman, M. Thynell, and R. van Voorst, Jakarta: Claiming Spaces and Rights in the City, Routledge, 2018.

[59] The International Bank for Reconstruction and Development, "Towards Efficient and Sustainable River Basin Operational Services in Indonesia," World Bank, Washington. Aug. 2015. [Online]. Available: http://documents.worldbank.org/curated/en/543681467987819510/pd f/100983-WP-P114348-PUBLIC-Box393254B-FINAL-Print-readyStudy-Report.pdf

[60] B. R. K. Dewi and J. A. van Ast, "Institutional Arrangements for Integrated Flood management of the Ciliwung-Cisadane River basin, Jakarta Metropolitan Area, Indonesia," in Urban Governance in the Realm of Complexity, M. P. van Dijk, J. Edelenbos, and K. van Rooujen Eds. Rugby, UK: Practical Action Publishing, 2017, ch. 14.

[61] Asian Development Bank, River Basin Management Planning in Indonesia: Policy and Practice. Manila, Philippines, 2016.

[62] V. Ariyanti, J. Edelenbos, and P. Scholten, "Implementing the integrated water resources management approach in a volcanic rive basin: a case study of Opak Sub-Basin, Indonesia," Area Dev. Pol. 2020, DOI. 10.1080/23792949.2020.1726785.

[63] WMO, "Community-based Flood Management," in "Integrated Flood Management Tools Series," World Meteorological Organisation and Global Water Partnership, Geneva, May 2017, no. 4. 
[64] M. O'Grady et al., "Supporting Participative Pre-Flood Risk Reduction in a UNESCO Biosphere," J. Flood Risk Man., 2019, DOI: doi.org/10.1111/jfr3.12520.

[65] M. Girons Lopez, "Information Needs for Water Resource and Risk Management: Hydro-meteorological data value and non-traditiona information," in "Digital Comprehensive Summaries of Uppsala Dissertations from the Faculty of Science and Technology 1419," Uppsala Univrsitet, Uppsala, 2016.

[66] M. A. Miller and M. Douglass, "Crossing Borders: Governing the Globalising Urban Matrix of Compound Disasters in Asia and the Pacific," in Crossing Borders: Governing Environmental Disasters in a Global Urban Age in Asia and the Pacific, M. A. Miller, M. Douglass, and M. Garschagen Eds. Singapore: Springer, 2018, ch. 1.

[67] A. Boin, "The Transboundary Crisis: Why are we unprepared and the road ahead," J. Cont. and Crisis Man., vol. 27, no. 1, pp. 94-99, 2019.

[68] BNPB, "Indonesia's Disaster Risk Management Baseline Status Report 2015. Towards identifying national and local priorities for the implementation of the Sendai Framework for Disaster Risk Reduction (2015-2030)," $2015 . \quad$ [Online]. Available: https://www.preventionweb.net/files/50832_5083220161031indobas elinereportfina.pdf

[69] N. Wijaya, M. B. F. Bisri, A. F. Aritenang, and A. Mariany, "Spatial Planning, Disaster Risk Reduction, and Climate Change Adaptation Integration in Indonesia: Progress, Challenges, and Approach," in Disaster Risk Reduction in Indonesia: Progress, Challenges and Issues, R. Djalante, F. Thomalla, M. Garschagen, and R. Shaw Eds.: Springer, 2017.

[70] P. Gleick and C. Iceland, "Water, Security and Conflict," in "Issue Brief," Water Resources Institute and the Pacific Institute, Washington DC. ISBN 1-56973-945-5, 2018

[71] A. K. Magnan et al., "Addressing the risk of maladaptation to climate change," WIRES Clim. Ch., vol. 7, no. 5, pp. 646-655, 2016.

[72] A. B. Rahman, "Mainstreaming Climate Change Adaptation in a Developing Country Context: An Indonesian Case Study," PhD, Sus. Pol. Inst., Curtin Univ., 2017.

[73] J. Lassa, "Negotiating Institutional Pathways for Sustaining Climate Change Resilience and Risk Governance in Indonesia," Climate, vol. 7 , no. 8 , p. 95,2019 